Ann. Biol. anim. Bioch. Biophys., 1978, 18 (4), 923-927.

\title{
Annual cycle of plasma oestradiol-17 $\beta$ in the female trout Salmo gairdneri
}

par J. G. D. LAMBERT, G. I. C. G. M. BOSMAN, R. VAN DEN HURK, P. G. W. J. VAN OORDT

Zoological Laboratory, Section Comparative Endocrinology, Padualaan 8, Utrecht, The Netherlands.

\begin{abstract}
Summary. Levels of oestradiol in plasma of adult female rainbow trout Salmogairdneri were determined during the annual reproductive cycle using a radioimmunoassay. From January to June, during previtellogenesis and the period of endogenous vitellogenesis plasma levels were low $(1,3 \pm 0,2 \mathrm{ng} / \mathrm{ml})$. At the beginning of the period of exogenous vitellogenesis, the cestradiol level rose and a maximum $(16,9 \pm 0,2 \mathrm{ng} / \mathrm{ml})$ was reached at the end of vitellogenesis in November, some weeks before spawning. A positive correlation $(r=0,58)$ was established between plasma cestradiol levels and the gonadosomatic index. From enzymatic cytochemical studies it was concluded that the granulosa cells, as well as the interstitial cells in the ovary, are involved in cestradiol production.
\end{abstract}

\section{Introduction.}

In oviparous vertebrates it is suggested that oestradiol-17 $\beta$ may trigger the liver to synthesize yolk proteins (for review : Clemens, 1974 ; Tata 1976). To test this hypothesis in Salmo gairdneri, we have studied the relation between oestradiol-17 $\beta$ levels in plasma during the annual cycle and the development of the oocytes; we have also investigated the location of the $3 \beta$-hydroxysteroid dehydrogenase enzyme in the ovary.

\section{Materials and methods.}

\section{Animals.}

Adult female specimens of the rainbow trout were obtained from a hatchery in Vaassen (the Netherlands). After anaesthesia with MS 222, blood was taken from the ductus Cuvieri with a heparinized vacuum syringe, then centrifuged and the plasma stored at $-20^{\circ} \mathrm{C}$. The ovaries were removed and prepared for histological and enzyme-cytochemical examination as described by van den Hurk ef al. (1978). 
Assay method for plasma oestradiol-17 $\beta$.

The organic solvents were redistilled once just before use. $\left(2,4,6,7(n){ }^{-3} \mathrm{H}\right)$ Oestradiol-17 $\beta$ (Spec. act. $109 \mathrm{Ci} / \mathrm{mmol}$ ) was obtained from the Radiochemical Centre (Amersham) and purified on TLC. The radioactivity was measured with a Nuclear Chicago Mark I scintillation counter with a scintillator of PPO $(5.4 \mathrm{~g})$ and POPOP $(100 \mathrm{mg})$ in toluene-triton $X 100(2: 1)$ mixture $(1 \mathrm{~L})$. Radioactive areas on the TLC plates were located by means of a Berthold thinlayer chromatogram scanner. Oestradiol-17 $\beta\left(E_{2}\right)$ was measured by radioimmunoassay. Antiserum (anti- $E_{2}-6-C M O-$ BSA) was obtained from Dr. R. J. Scaramuzzi (MRC unit for Reproductive Biology, Edinburgh, Scotland, U. K.) through Dr. S. J. Dieleman (Clinic for Veterinary Obstetrics, Gynaecology and A. I., Utrecht, the Netherlands). The antiserum had a high specificity; cross reactions with oestrone and oestradiol-17 $\alpha$ were 3 p. 100 and 1.2 p. 100 respectively. For the assay of plasma $E_{2}, 1 \mathrm{ml}$ of plasma was added to an extraction tube together with $2000 \mathrm{dpm}$ of ${ }^{3} \mathrm{H}-\mathrm{E}_{2}$. After one hour at room temperature, extraction was performed with peroxide-free diethylether $(2 \times 5 \mathrm{ml})$. The combined ether fraction was evaporated under nitrogen at $40^{\circ} \mathrm{C}$ and the residue dissolved in $2 \mathrm{ml}$ of buffer containing $\mathrm{Na}_{2} \mathrm{HPO}_{4}-2 \mathrm{H}_{2} \mathrm{O}(10.78 \mathrm{~g}), \mathrm{NaH}_{2} \mathrm{PO}_{4}-\mathrm{H}_{2} \mathrm{O}(5.4 \mathrm{~g}), \mathrm{NaN}_{3}(1 \mathrm{~g})$, $\mathrm{NaCl}(9 \mathrm{~g})$, gelatine $(1 \mathrm{~g})$ per litre aqua dest. From the sample $400 \mu \mathrm{l}$ was counted for recovery determinations and $100 \mu \mathrm{l}$ and $200 \mu \mathrm{l}$ aliquots (both in duplo) were transferred to assay tubes containing $15000 \mathrm{dpm}{ }^{3} \mathrm{H}-\mathrm{E}_{2}$. In all tubes the volume was raised, if necessary, to $200 \mu \mathrm{l}$ with buffer. A standard curve was set up by adding $15000 \mathrm{dpm}{ }^{3} \mathrm{H}-\mathrm{E}_{2}$ to a series of assay tubes containing $0,25,50,100,150,200,300$ and $400 \mathrm{pg}$ unlabeled $\mathrm{E}_{2}$. After adding $200 \mu \mathrm{l}$ of antiserum $(1: 60000)$ and vortex mixing, the tubes were incubated overnight at $4{ }^{\circ} \mathrm{C}$. To separate the free and bound $E_{2}$, all assay tubes were closed with plastic caps containing $200 \mu \mathrm{l}$ of dextran-coated charcoal in buffer. Following incubation, the assay samples were simultaneously mixed with charcoal by shaking the fubes. After a contact time of $5 \mathrm{~min}$. the charcoal was centrifuged and $100 \mu \mathrm{l}$ of the supernatant, containing the bound $E_{2}$, was measured. The binding percentage was calculated and after adjustment for recovery $(70-90 \mathrm{p}$. 100), values were expressed as $\mathrm{ng} / \mathrm{ml}$ plasma. For determining the unspecific binding, a blank of $1 \mathrm{ml}$ of buffer was run through the entire procedure. The value of the blanks was $0.017 \mathrm{ng} / \mathrm{ml}$. Intra-assay precision was determined by a tenfold analysis in the optimal range from 25 to $200 \mathrm{pg}$. The coefficients of variation for analysis of $25,50,100,150$ and $200 \mathrm{pg}$ were 10.7, 4.1, 2.1, 1.2 and 0.7 p. 100 respectively.

\section{Results.}

Histological studies showed annual changes in the growth and ripening of ovarian follicles. In the cycle, three pericds could be distinguished. 1 . The period of previtellogenesis, from January to June, characterized by the presence of young follicles (max. diameter $0.3 \mathrm{~mm}$ ) and the differentiation of the follicular layer into granulosa and theca. 2. The period of endogenous vitellogenesis, which is restricted to May and June. In this period, the oocytes reach a diameter of $0.6 \mathrm{~mm}$, as a result of endogenous yolk formation. Part of this process is the appearance of cytoplasmic vacuoles with chromophobic contents. 3 . The period of exogenous vitellogenesis, during which 
the oocytes take up yolk proteins and grow to $4.5 \mathrm{~mm}$. This period lasts from July to December. In December or January, ovulation may take place, leading to the formation of postovulatory follicles. The enzyme $3 \beta$-hydroxysteroid dehydrogenase $(3 \beta-H S D)$ has been demonstrated in the granulosa cells of growing follicles during the first half of the period of exogenous vitellogenesis (fig. 1), in interstitial cells during the entire cycle (peak in January), and in the postovulatory follicles. In comparison with the strong activity of the surrounding interstitial cells, the $3 \beta$-HSD activity in the granulosa cells of the postovulatory follicles is rather weak (fig. 2). The plasma $E_{2}$ levels were determined at irregular intervals for $11 / 2$ year. The individual $E_{2}$ levels are presented in table 1 and figure 3. Both in 1975 and 1976, they clearly followed a seasonal pattern.
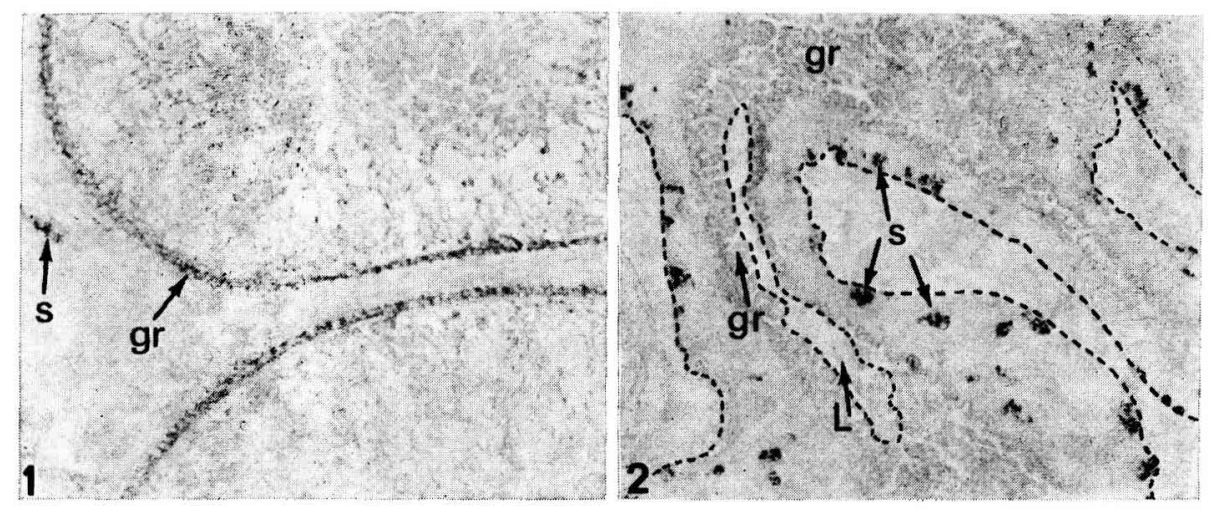

FIG. 1 and 2. - 3 $\beta-H S D$ activity in the ovary of Salmo gairdneri.

1. Detail of two growing follicles.

2. Detail of a corpus luteum :

gr : granulosa cells ; $L$ : lumen of the corpus luteum ; $s$ : stromal or interstitial cells.

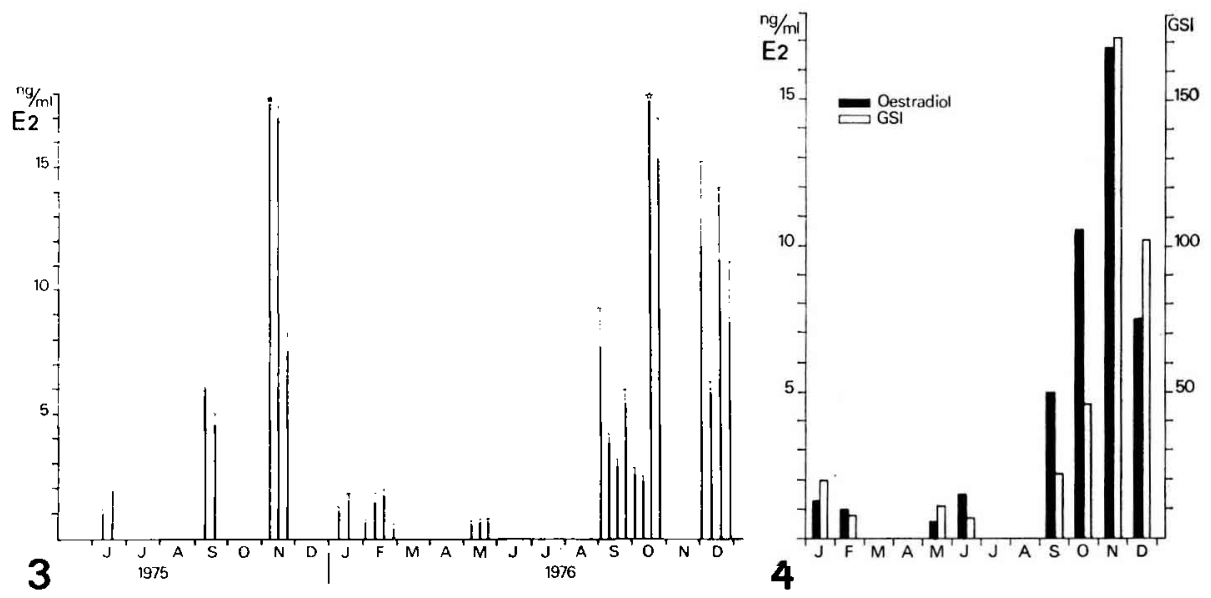

FIG. 3 and 4. - Seosonal changes in the concentrations of plasma oestradiol-17 $\beta$ in female Salmo gairdneri.

3. The individual $E_{2}$ levels $(\mathrm{ng} / \mathrm{ml})$ during 1975 and 1976.

4. The mean values of $E_{2}$ levels and gonado-somatic index (GSI p. 1000 ) during an annual cycle. 
The cyclical changes have been summarized in figure 4. A rise in $E_{2}$ level obviously starts before September, probably in July or August. After a maximum in November $(16.9 \pm 0.2 \mathrm{ng} / \mathrm{ml})$, the values drop to $1.3 \pm 0.2 \mathrm{ng} / \mathrm{ml}$ in January. Such low values last to June. Comparison of the plasma $E_{2}$ levels with the gonadosomatic index (GSI) of individual animals (table 1 ) indicate a positive correlation (correlation coefficient after Ferguson, $1966: 0.58$ ) (fig. 4).

\section{TABLE 1}

The oestradiol-17 $\beta$ (E2) levels in plasma of Salmo gairdneri. GSI : gonadosomatic index, (n) : number of assays

\begin{tabular}{|c|c|c|c|}
\hline \multirow{3}{*}{$\begin{array}{c}\text { Date } \\
3-6-1975\end{array}$} & \multirow{3}{*}{$\begin{array}{c}\text { GSI (p. } 1000) \\
4.9 \\
8.8\end{array}$} & \multicolumn{2}{|c|}{ E2 $n g / m l(n)$} \\
\hline & & $1.0 \pm 0.1$ & (11) \\
\hline & & $1.9 \pm 0.2$ & (13) \\
\hline \multirow[t]{2}{*}{ 24-9-1975 } & 30.1 & $6.0 \pm 1.1$ & $(7)$ \\
\hline & 18.8 & $4.5 \pm 0.5$ & (7) \\
\hline \multirow[t]{3}{*}{ 19-11-1975 } & 164.4 & $26.2 \pm 0.6$ & (2) \\
\hline & 247.5 & $17.0 \pm 0.9$ & (4) \\
\hline & 86.7 & $7.5 \pm 1.3$ & (3) \\
\hline \multirow[t]{2}{*}{$7-1-1976$} & 10.4 & $1.1 \pm 0.2$ & (14) \\
\hline & 38.5 & $1.5 \pm 0.3$ & (11) \\
\hline \multirow{3}{*}{$25-2-1976$} & 6.8 & $0.6 \pm 0.1$ & (7) \\
\hline & 6.6 & $0.4 \pm 0.1$ & (5) \\
\hline & - & $1.7 \pm 0.2$ & (13) \\
\hline \multirow[t]{3}{*}{$5-5-1976$} & 10.6 & $0.6 \pm 0.1$ & (7) \\
\hline & 6.1 & $0.6 \pm 0.1$ & (9) \\
\hline & 14.6 & $0.5 \pm 0.1$ & (15) \\
\hline \multirow[t]{4}{*}{$23-9-1976$} & 28.9 & $7.7 \pm 1.6$ & (12) \\
\hline & 20.4 & $3.8 \pm 0.4$ & (15) \\
\hline & 18.6 & $2.9 \pm 0.4$ & (12) \\
\hline & 26.1 & $5.4 \pm 1.9$ & (9) \\
\hline \multirow[t]{4}{*}{$21-10-1976$} & 14.1 & $2.5 \pm 0.4$ & (7) \\
\hline & 38.7 & $2.3 \pm 0.2$ & (8) \\
\hline & 47.8 & $22.1 \pm 3.6$ & (6) \\
\hline & 80.9 & $15.4 \pm 1.6$ & (10) \\
\hline \multirow[t]{4}{*}{$2-12-1976$} & 251.8 & $5.8 \pm 0.4$ & (4) \\
\hline & 80.1 & $11.2 \pm 3.1$ & (4) \\
\hline & 78.0 & $8.7 \pm 2.5$ & (3) \\
\hline & - & $11.8 \pm 3.4$ & (5) \\
\hline
\end{tabular}

\section{Discussion.}

Comparing radioimmunoassay and histological results, it appears that plasma $E_{2}$ levels are low during endogenous vitellogenesis and increase with the beginning of exogenous vitellogenesis. This increase continues throughout the period of exogenous yolk formation, and a maximum is reached some weeks before spawning. Schreck et al., (1973) found $4.4 \mathrm{ng} \mathrm{E}_{2}$ per $\mathrm{ml}$ plasma in adult female Salmo gairdneri in October. Judging from this value, the blood samples must have been collected before the $E_{2}$ levels reached maximum value. The correlation between the change in plasma $E_{2}$ level and exogenous vitellogenesis corresponds to the observations of Eleftheriou ef al., (1966), Schreck and Hopwood (1974) and Wingfield and Grimm (1977) in other 
teleosts, and also with the hypothesis that $E_{2}$ triggers the synthesis of yolk proteins in the liver (Clemens, 1974 ; Tata, 1976). The continuous presence of $E_{2}$ in the blood corresponds to the uninterrupted activity of $3 \beta-H S D$ in the interstitial cells of the ovary. The increase in plasma $E_{2}$ levels coincides with the development of $3 \beta-H S D$ activity in the granulosa cells of the follicles. These correlations seem to indicate that $E_{2}$ is formed both in the interstitium and in the granulosa cells of growing follicles. During October and November, the plasma $E_{2}$ level continues to rise, but this is not reflected by an increased $3 \beta-$ HSD activity in the ovary. On the contrary, during this period, $3 \beta-H S D$ activity could not be demonstrated in the granulosa cells. This might be attributed to the fact that the oocytes become very large and cause stretching of the granulosa cells. A slight $3 \beta-H S D$ activity is again noticeable in the granulosa cells after ovulation and collapse of the follicle. The presence of some 3 $\beta$-HSD activity in the postovulatory follicles coincides with a maximum 3 $3-H S D$ activity in the interstitial tissue, which is not reflected by a rise in plasma $E_{2}$. This means that the $3 \beta-H S D$ activity cannot be used as parameter for $E_{2}$ production, and that next to $E_{2}$ other steroids are being synthesized by the ovary during the annual cycle. On the other hand, the positive correlation in Salmo gairdneri between plasma $E_{2}$ level and GSI seems to indicate that the latter can be used for estimating $E_{2}$ production.

Symposium sur la Reproduction des Poissons Paimpont, France, 19-21 septembre 1977.

Résumé. Les niveaux d'estradiol dans le plasma de femelles truites adultes ont été déterminés durant le cycle reproducteur annuel en utilisant un dosage radioimmunologique. De janvier à juin, pendant la prévitellogenèse et la période de vitellogenèse endogène, les niveaux plasmatiques sont faibles $(1,3 \pm 0,2 \mathrm{ng} / \mathrm{ml})$. Au début de la période de vitellogenèse exogène les niveaux d'estradiol augmentent et un maximum $(16,9 \pm 0,2 \mathrm{ng} / \mathrm{ml})$ est atteint à la fin de la vitellogenèse en novembre, quelques semaines avant la fraie. Une corrélation positive $r=0,58$ a été calculée entre l'estradiol plasmatique et le rapport gonado-somatique. A partir d'études cytoenzymologiques on conclut que les cellules de la granulosa comme les cellules interstitielles de l'ovaire sont impliquées dans la production d'estradiol.

\section{References}

CLEMENS M. J., 1974. The regulation of egg yolk protein synthesis by steroid hormones. Prog. Biophys. mol. Biol., 28, 71-107.

ELEFTHERIOU B. E., BOEHLKE K. W., TIEMEIER O. W., 1966. Free plasma estrogens in the channel catfish. Proc. Soc. exp. Biol. Med., 121, 85-88.

FERGUSON G. A., 1966. In : Statistical analysis in psychology and education. McGraw-Hill, London. HURK R. van den, VERMEIJ, J. A. J., STEGENGA J., PEUTE J., van OORDT P. G. W. J., 1978. Cyclic changes in the testis and vas deferens of the rainbow trout, Salmo gairdneri, with special reference to sites of steroidogenesis. Ann. Biol. anim. Biochim. Biophys., 18, 899-904.

SCHRECK C. B., HOPWOOD, M. L., 1974. Seasonal androgen and estrogen patterns in the goldfish, Carassius auratus. Trons. amer. Fish. Soc., 103, 375-378.

SCHRECK C. B., LACKEY R. T., HOPWOOD M. L., 1973. Plasma oestrogen levels in rainbow trout, Salmo gairdneri Richardson. J. Fish. Biol., 5, 227-230.

TATA J. R., 1976. The expression of the vitellogenin gene ; review. Cell, 9, 1-14.

WINGFIELD J. C., GRIMM A. S., 1977. Seasonal changes in plasma cortisol, testosterone and oestradiol-17 $\beta$ in the plaice, Pleuronectes platessa. Gen. comp. Endocrin., 31, 1-11. 